\title{
JUAL BELI BORONGAN BAWANG MERAH DI DESA GRINTING MENURUT TINJAUAN HUKUM ISLAM
}

\author{
Juju Jumena, A. Otong Busthomi dan Husnul Khotimah \\ Fakultas Syariah dan Ekonomi Islam \\ Institut Agama Islam Negeri Syekh Nurjati Cirebon \\ e-mail: jumena72@yahoo.com,tomibust@yahoo.com \\ dankhotimah.husnul02@gmail.com
}

\begin{abstract}
In the community often there is buying and selling done to obtain ease without knowing whether the sale is done that is in accordance with the concept of Islamic law or not, as happened in the sale and purchase of red onion with bulk system in Grinting village. In practice, physically object of buying and selling not yet known quantity. Seeing the problem, the writer feels the need to study more deeply based on the review of Islamic law. The method used in this research is to use qualitative by utilizing the sociology approach of Islamic law. Technique of collecting date that is done observation, interview and documentation. From the research results obtained the forms of sale and purchase of red onion in Grinting village there are 2 namely Scales (small scale Rogolan and Gedengan in a typical gift shop) and Borongan (large scale Rogolan, Gedengan, Larikan and Tebasan). According to the review of Islamic law in buying and selling of wholesalers is done under the terms of jizaf, so if meet the conditions of buying and selling jizaf then the sale is legal or allowed.
\end{abstract}

Keywords: Sale and Purchase Wholesale (Jizaf), Red Onion, Islamic Economic Law.

\begin{abstract}
Abstrak
Di masyarakat sering kali terdapat jual beli yang dilakukan untuk memperoleh kemudahan tanpa mengetahui apakah jual beli yang dilakukan itu sudah sesuai dengan konsep hukum Islam atau tidak, sebagaimana yang terjadi dalam jual beli bawang merah dengan sistem borongan di desa Grinting. Dalam praktiknya, secara fisik obyek dari jual beli belum diketahui kuantitasnya. Melihat permasalahan tersebut, penulis merasa perlu mengkaji lebih dalam lagi berdasarkan tinjauan hukum Islam. Metode yang digunakan dalam penelitian ini adalah kualitatif dengan memanfaatkan pendekatan sosiologi hukum Islam. Teknik pengumpulan data yang dilakukan, yaitu observasi, wawancara dan dokumentasi. Dari hasil penelitiannya diperoleh bentuk-bentuk jual beli bawang merah di desa Grinting ada 2 yaitu Timbangan (Rogolan skala kecil dan Gedengan di Toko Oleh-oleh) dan Borongan (Rogolan skala besar, Gedengan, Larikan dan Tebasan). Menurut tinjauan hukum Islam dalam melakukan jual beli borongan dilakukan berdasarkan ketentuan syarat jizaf, sehingga apabila memenuhi syarat-syarat jual beli jizaf maka jual belinya sah atau diperbolehkan.
\end{abstract}

Kata Kunci: Jual Beli Borongan (Jizaf), Bawang Merah, Hukum Ekonomi Islam. 


\section{PENDAHULUAN}

Agama Islam mengatur setiap segi kehidupan umatnya, yaitu mengatur hubungan seorang hamba dengan Tuhannya yang biasa disebut muamalah ma'allah dan mengatur pula hubungan dengan sesamanya yang biasa disebut dengan muamalah ma'annas. Persoalan muamalah merupakan suatu hal yang pokok dan menjadi tujuan penting dari agama Islam dalam upaya memperbaiki kehidupan manusia. Masalah muamalah ini senantiasa terus berkembang, tetapi perlu diperhatikan agar perkembangan tersebut tidak menimbulkan kesulitan di antara sesamanya. Salah satu bentuk perwujudan muamalah ma'annas yang disyariatkan oleh Allah SWT adalah kegiatan jual beli. ${ }^{1}$

Jual beli adalah pertukaran harta atas dasar saling rela atau memindahkan milik dengan ganti yang dapat dibenarkan, yaitu berupa alat tukar yang sah. ${ }^{2}$ Berdasarkan kaidah umum tentang muamalah, maka dalam kegiatan jual beli orang yang berdagang harus mengetahui apa yang sebaiknya diambil dan apa yang sebaiknya ditinggalkan, mengetahui mana yang halal dan mana yang haram, serta tidak memasukan unsur riba dengan cara-cara yang tidak diketahui oleh pembeli. ${ }^{3}$ Untuk mengantisipasi hal-hal yang tidak diinginkan baik dari pihak penjual maupun pembeli, maka seharusnya memenuhi syarat-syarat sahnya jual beli, yaitu pertama, saling rela antara kedua belah pihak. Kedua, pelaku akad adalah orang yang dibolehkan melakukan akad, yaitu orang yang telah baligh, berakal dan mengerti. Ketiga, harta yang menjadi objek transaksi telah dimiliki. Keempat, objek

\footnotetext{
${ }^{1}$ Shaleh Bin Fuazan al-Fauzan, Mulakhkhas Fiqih, Jilid 2 (Jakarta: Pustaka Ibnu Katsir, 2013), 21.

${ }^{2}$ Suhrawardi K. Lubis dan Farid Wajdi, Hukum Ekonomi Islam (Jakarta: Sinar Grafika, 2012), 139.

${ }^{3}$ Abdurrahman as-Sa'ad, et al., Fiqih Jual Beli: Panduan Praktis Bisnis Syariah, terj. Abdullah (Jakarta: Senayan Publishing, 2008), 7.
}

transaksi adalah barang yang dibolehkan agama. Kelima, objek transaksi adalah barang yang biasa diserahterimakan. Keenam, objek jual beli diketahui oleh kedua belah pihak saat akad. Dan ketujuh, harga harus jelas saat transaksi. ${ }^{4}$

Pada praktiknya, yang terjadi di masyarakat kita adalah banyak sekali cara untuk melakukan jual beli. Salah satu diantaranya adalah pada bidang pertanian, yaitu jual beli borongan pada bawang merah di Desa Grinting Kabupaten Brebes. Jual beli borongan tersebut dilakukan dengan menggunakan sistem taksiran, yang mana dalam hal perhitungan kuantitasnya tidak perlu menggunakan timbangan lagi. Jual beli borongan ini banyak terjadi antara petani dan tengkulak, atau antara tengkulak dengan pemasok yang sudah terbiasa melakukan jual beli seperti ini sejak lama.

Cara ini memang memungkinkan terjadinya spekulasi dari kedua belah pihak, karena kualitas dan kuantitas bawang merahnya belum tentu jelas keadaan dan kebenaran perhitungannya. Hal ini dikarenakan dalam perhitungannya dilakukan tanpa adanya penakaran dan penimbangan yang sempurna. Selain masalah perhitungan, banyak terjadi perbedaan pendapat diantara para ulama mengenai jual beli borongan atau tebasan ini. Untuk itu maka penulis merasa perlu untuk mengkaji lebih dalam lagi mengenai 1) Bagaimana bentuk-bentuk jual beli bawang merah di Desa Grinting Kabupaten Brebes? 2) Bagaimana praktik jual beli bawang merah dengan sistem borongan di Desa Grinting Kabupaten Brebes? 3) Bagaimana tinjauan hukum Islam terhadap praktik jual beli bawang merah dengan sistem borongan di Desa Grinting Kabupaten Brebes?

${ }^{4}$ Mardani, Fiqh Ekonomi Syariah (Jakarta: Kencana, 2012), 104-105. 


\section{LITERATURE REVIEW}

Penelitian tentang jual beli bawang merah dengan sistem borongan bukanlah suatu yang baru. Meskipun demikian, nampaknya belum ditemukan penelitian yang secara spesifik dikaji dari segi sosilogi hukum Islam. Berikut beberapa karya yang terdokumentasikan terkait permasalahan yang dikaji, yaitu pertama, penelitian yang dilakukan oleh Irfatun Na'imah. ${ }^{5}$ Penelitian ini memfokuskan kepada jual beli ikan yang masih di dalam telaga atau kolam dengan sistem tebasan dalam prespektif hukum Islam. Menurutnya, dalam proses jual beli ikan dengan sistem tebasan ini masih belum ada kejelasan objeknya, karena ikannya masih ada di dalam kolam dan tidak ada proses pembibitan, serta pemeliharaan. Akan tetapi ketidakjelasan ini terhapuskan karena adanya pembuktian objek jual beli oleh pembeli dan ada penjelasan dari penjual. Dalam jual beli ini dikatakan sah menurut hukum Islam, karena sudah sesuai dengan rukun dan syarat jual beli, yaitu kejelasan objeknya sebagaimana yang dimaksud di atas.

Dan kedua, penelitian yang dilakukan oleh Ayyun Herbiyati, ${ }^{6}$ tentang "Tinjauan Maslahah terhadap Jual Beli Borongan Jagung (Studi Kasus di Desa Buntalan Kecamatan Temayang Kabupaten Bojonegoro Tahun 2013)". Dalam penelitian ini muncul permasalahan pokok, yaitu adanya keterpaksaan di antara salah satu pihak, yakni petani. Petani merasa dirugikan dengan tidak adanya kesepakatan harga diawal transaksi. Akan tetapi pada praktiknya, penelitian ini mencoba menerapkan teori maslahah, sehingga pada

\footnotetext{
${ }^{5}$ Irfatun $\mathrm{Na}$ 'imah, “Tinjauan Hukum Islam Terhadap Praktek Jual Beli Ikan dengan Sistem Tebasan di Desa Sekaran Kecamatan Sekaran Kabupaten Lamongan". (Skripsi, Fakultas Syari'ah dan Hukum UIN Sunan Kalijaga Yogyakarta, 2012.

${ }^{6}$ Ayyun Herbiyati, "Tinjauan Maslahah Terhadap Jual Beli Borongan Jagung. (Studi Kasus di Desa Buntalan Kecamatan Temayang Kabupaten Bojonegooro Tahun 2013)". (Skripsi. Fakultas Syari'ah IAIN Sunan Ampel Surabaya, 2014).
}

kesimpulannya jual beli yang dimaksud harus diperbaiki dari segi transaksinya agar dapat dinilai sesuai dan benar menurut hukum Islam.

Dari kedua topik penelitian yang telah dipaparkan di atas, ternyata belum ada tinjauan secara khusus dan komprehensif tentang jual beli bawang merah dengan sistem borongan yang secara spesifik dikaji dari segi sosilogi hukum Islam. Dengan menggunakan pendekatan sosiologi hukum Islam ini, selain nantinya akan tergambar karakteristik praktik jual beli borongan, diharapkan penelitian ini juga akan mengungkapkan nuansa pembaharuan pemikiran hukum Islam sesuai dengan perkembangan saat ini. Di sinilah letak perbedaan studi ini dengan studi-studi yang telah dilakukan sebelumnya.

\section{METODOLOGI PENELITIAN}

Jenis penelitian yang digunakan adalah penelitian lapangan. ${ }^{7}$ Penelitian lapangan merupakan penelitian yang dilakukan dalam kehidupan sehari-hari atau kehidupan yang sebenarnya. Ide penting dalam penelitian lapangan ini adalah peneliti berangkat untuk mengadakan pengamatan terhadap suatu fenomena dalam suatu keadaan alamiah. ${ }^{8}$ Pada penelitian lapangan ini peneliti mengamati fenomena yang terjadi dalam praktik jual beli bawang merah dengan menggunakan sistem borongan di desa Grinting Kecamatan Bulakamba Kabupaten Brebes pada bulan Februari-April 2017 dengan membuat catatan yang ekstensif.

Metode yang digunakan dalam penelitian ini adalah metode kualitatif, yaitu peneliti bermaksud untuk memahami fenomena tentang apa yang dialami oleh subjek penelitian seperti, perilaku, persepsi, motivasi, tindakan dan lainnya, secara holistik dan dengan suatu konteks khusus

${ }^{7}$ Lexy J. Moleong, Metode Penelitian Kualitatif (Bandung: Remaja Rosdakarya, 2014), 26.

${ }^{8}$ Lexy J. Moleong, Metode Penelitian Kualitatif, 27. 
yang alamiah dan dengan memanfaatkan berbagai metode alamiah pula. ${ }^{9}$

Pendekatan penelitian yang dilakukan menggunakan pendekatan sosiologi hukum Islam, yaitu melihat kejadian sesuai realita sebagai fenomena sosial. Pada praktiknya, hal ini dilakukan untuk mengetahui eksistensi perspektif hukum Islam dalam praktik jual beli bawang merah dengan sistem borongan yang ada di Desa Grinting.

Sumber data yang diperlukan adalah data primer dan data sekunder. Data primer didapatkan melalui wawancara dengan informan diantaranya petani bawang merah, tengkulak dan pemasok. Adapun data sekunder yang digunakan di sini yaitu, skripsi, jurnal dan website yang berkaitan dengan jual beli borongan, serta data dari kantor Balai Desa Grinting.

Metode pengumpulan data yang digunakan adalah observasi, wawancara dan dokumentasi. Pertama, dilihat dari segi proses pengumpulan data, observasi dapat dibedakan menjadi dua, yaitu observasi berperan serta dan observasi tidak berperan serta. ${ }^{10}$ Pada teknik pengumpulan data dengan observasi ini peneliti menggunakan observasi non participant observation (observasi tidak berperan serta), dalam teknik ini peneliti hanya sebagai pengamat independen tanpa ikut terlibat langsung dengan aktivitas orang-orang yang sedang diamati. Peneliti mengamati bagaimana perilaku masyarakat dalam praktik jual beli bawang merah dengan sistem borongan, kemudian mencatat, menganalisis dan kemudian dapat membuat kesimpulan. Kedua, wawancara adalah proses memperoleh keterangan untuk tujuan penelitian dengan cara tanya jawab, sambil bertatap muka antara pewawancara dengan responden dengan menggunakan alat yang

\footnotetext{
${ }^{9}$ Lexy J. Moleong, Metode Penelitian Kualitatif, 27.

${ }^{10}$ Sugiono, Metode Penelitian Kuantitatif Kualitatif dan $R$ \& D (Bandung: Alfabeta, 2012), 145.
}

dinamakan panduan wawancara. ${ }^{11}$ Dalam hal ini peneliti mewawancarai beberapa informan yang aktif melakukan praktik jual beli bawang merah dengan sistem borongan di Desa Grinting seperti petani dan tengkulak.

Dan Ketiga, dokumentasi adalah mencari data mengenai hal-hal atau variabel yang berupa catatan, transkrip, buku, surat kabar, majalah, prasasti dan sebagainya. ${ }^{12}$ Maksud dari dokumentasi ini peneliti mencari sumber-sumber data yang lain selain wawancara dan observasi yang berkaitan dengan kajian yang dibahas. Seperti misalnya buku-buku yang relevan, laporan kegiatan, foto-foto, film dokumenter dan data yang relevan.

Penelitian ini menggunakan teknis analisis data yang bersifat induktif berdasarkan data yang diperoleh, selanjutnya dikembangkan menjadi hipotesis. Hipotesis yang dirumuskan berdasarkan data tersebut, selanjutnya dicarikan data lagi secara berulang-ulang sehingga selanjutnya dapat disimpulkan apakah hipotesis tersebut diterima atau ditolak berdasarkan data yang terkumpul. Apabila data yang dikumpulkan ternyata diterima, maka hipotesis tersebut berkembang menjadi teori.

\section{KONSEP DASAR}

\section{Jual Beli dalam Islam}

Jual beli atau perdagangan dalam istilah fiqh disebut $a l-b a ' i$ yang menurut etimologi berarti menjual atau mengganti. Wahbah alZuhaily mengartikannya secara bahasa dengan "menukar sesuatu dengan sesuatu yang lain". Kata $a l-b a ' i$ dalam bahasa arab terkadang digunakan untuk pengertian lawannya, yaitu kata al-syira' (beli). Dengan demikian, kata $a l-b a$ ' $i$ berarti jual, tetapi sekaligus juga berarti beli.

\footnotetext{
${ }^{11}$ Nur Aswani dan Masyhuri, Metodologi Riset Manajemen Pemasaran, 163.

${ }^{12}$ Suharsimi Arikunto, Prosedur Penelitian: Suatu Pendekatan Praktik, 236.
} 
Secara terminologi, dikemukakan oleh ulama Hanafiyah yang dikutip oleh Wahbah al-Zuhaily, jual beli adalah saling tukar harta dengan harta melalui cara tertentu atau tukar-menukar sesuatu yang diinginkan dengan yang sepadan melalui cara tertentu yang bermanfaat. $^{13}$ Berdasarkan definisi di atas, maka pada intinya jual beli itu adalah tukar menukar barang. Hal itu telah dipraktikan oleh masyarakat primitive ketika uang belum digunakan sebagai alat tukar-menukar barang, yaitu dengan sistem barter yang dalam terminology fiqh disebut dengan $b a$ ' $i$ al-muqayyadah. Meskipun jual beli dengan sistem barter telah ditinggalkan dan diganti dengan sistem mata uang, tetapi terkadang esensi jual beli seperti itu masih berlaku, sekalipun untuk menentukan jumlah barang yang ditukar tetap diperhitungkan dengan nilai mata uang tertentu, misalnya Indonesia membeli spare part kendaraan ke Jepang, maka barang yang di import itu dibayar. ${ }^{14}$

\section{Dasar Hukum Jual Beli}

Jual beli sebagai sarana tolong-menolong antara sesama umat manusia mempunyai landasan yang kuat dalam Al-Qur'an dan sunah Rasulullah saw. Terdapat beberapa ayat al-Qur'an dan sunah Rasulullah saw. yang berbicara tentang jual beli, antara lain :

$$
\text { وَأَحَحَلَ اللَّهُ الْبَيْعَ وَحَرَّمَ الرِبَا }
$$

Artinya: Allah telah menghalalkan jual beli dan mengharamkan riba. ${ }^{15}$

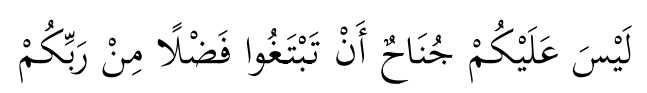

Artinya: Tidak ada dosa bagimu untuk mencari karunia (rezeki hasil perniagaan) dari Tuhanmu. ${ }^{16}$

\footnotetext{
${ }^{13}$ Abdul Rahman Ghazaly, et al., Fiqih Muamalat (Jakarta: Kencana, 2010), 67.

${ }^{14}$ Mardani, Fiqh Ekonomi Syariah Fiqh Muamalah, 101.

${ }^{15}$ QS. Al-Baqarah (2): 275.

${ }^{16}$ QS. Al-Baqarah (2): 198.
}

$$
\text { إلاَّا أَنْ نَكُونَ تِحَارَة عَنْ تَرَاضٍ مِنْكُمْ }
$$

Artinya: ...kecuali dengan jalan perniagaan yang berlaku dengan suka sama-suka di antara kamu. ${ }^{17}$

Dasar hukum jual beli berdasarkan sunah Rasulullah, antara lain:

Hadits yang diriwayatkan oleh Rifa'ah ibn Rafi' :

$$
\begin{aligned}
& \text { عَنْ رِفَاعَةَ بْنِ رَافِعِ رَضِيَِ اللهُ عَنْهُ أَنَّ النَّبَِّ صَلَّى اللَّه }
\end{aligned}
$$

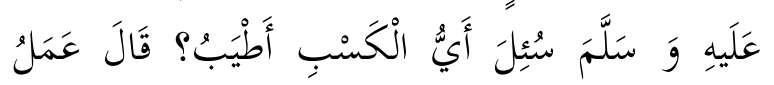

$$
\begin{aligned}
& \text { الرَّجُلِ بِيَدِدِ وَكُكُ بَيْعِ مَبْرُوْرِ }
\end{aligned}
$$

Artinya: Rasulullah saw, ditanya salah seorang sahabat mengenai pekerjaan (profesi) apa yang paling baik, Rasulullah saw, menjawab : Usaha tangan manusia sendiri dan setiap jual beli yang diberkati. ${ }^{18}$

Hadits dari al-Baihaqi, Ibn Majah dan Ibn Hibban, Rasulullah menyatakan:

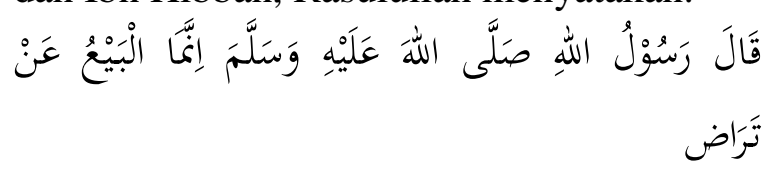

Artinya: Jual beli itu didasarkan atas suka sama suka". 19

Hadits yang diriwayatkan al-Tirmizi, Rasulullah saw bersabda:

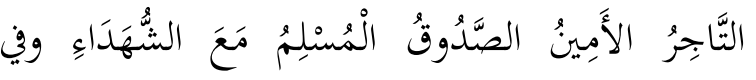

$$
\begin{aligned}
& \text { رواية: مع النبيين و الصديقين و الشهداء يَوْمَ الْقِيَامَةِ }
\end{aligned}
$$

Artinya: Pedagang yang jujur dan terpercaya sejajar (tempatnya di surga) dengan para nabi, dan syuhada". 20

\footnotetext{
${ }^{17}$ QS. An-Nisa' (4): 29.

${ }^{18} \mathrm{HR}$. Al-Bazzar dan Al-Hakim, diambil dari buku Abdul Rahman Ghazaly, et al., Fiqih Muamalat, 69.

${ }^{19}$ HR. Ibn Majah, diambil dari buku Abdul Rahman Ghazaly, et al., Fiqih Muamalat, 69.

${ }^{20}$ HR. al-Tirmizi, diambil dari buku Abdul Rahman Ghazaly, et al., Fiqih Muamalat, 69.
} 
Dari kandungan ayat-ayat al-Qur'an dan sabda-sabda Rasul diatas, para ulama fiqh menyatakan bahwa hukum asal dari jual beli yaitu mubah (boleh).

\section{Rukun dan Syarat Sah Jual Beli}

Rukun jual beli ada 3 (tiga) macam, yaitu Adanya pihak penjual dan pembeli (orang yang berakad), adanya lafal atau Shigat atau ijab qabul dan adanya barang (uang dan benda). Dalam suatu perbuatan jual beli, ketiga rukun itu hendaklah dipenuhi, sebab apabila salah satu rukunnya tidak terpenuhi, maka perbuatan tersebut tidak dapat dikategorikan sebagai perbuatan jual beli. ${ }^{21}$

Adapun syarat sah jual beli sesuai dengan rukun jual beli yang dikemukakan Jumhur ulama, yaitu pertama, syarat-syarat orang yang berakad ('Aqid) yaitu berakal dan yang melakukan akad itu adalah orang yang berbeda. Artinya, seseorang tidak dapat bertindak dalam waktu yang bersamaan sebagai penjual sekaligus sebagai pembeli. ${ }^{22}$

Kedua, syarat-syarat yang terkait dengan Ijab Kabul (Sigat al 'aqad). Para ulama fiqh sepakat bahwa unsur utama dari jual beli yaitu kerelaan kedua belah pihak. Kerelaan kedua belah pihak dapat dilihat dari ijab dan kabul yang dilangsungkan. Apabila ijab kabul telah diucapkan dalam akad jual beli maka pemilikan barang atau uang telah berpindah tangan dari pemilik semula. Barang yang dibeli berpindah tangan menjadi milik pembeli dan nilai/uang berpindah tangan menjadi milik penjual. Di zaman modern, perwujudan ijab dan Kabul tidak lagi diucapkan, tetapi dilakukan dengan sikap mengambil barang dan membayar uang oleh pembeli, serta menerima uang dan menyerahkan barang oleh penjual tanpa ucapan apapun. Misalnya, jual beli yang berlangsung di swalayan. Dalam fiqh Islam, jual beli seperti

\footnotetext{
${ }^{21}$ Suhrawardi K. Lubis dan Farid Wajdi, Hukum Ekonomi Islam, 140.

${ }^{22}$ Abdul Rahman Ghazaly, et al., Fiqih Muamalat, 72.
}

ini disebut dengan ba'i al-mua'thah. Dalam kasus perwujudan ijab dan kabul melalui sikap ini (ba'i al-mua'thah) terdapat perbedaan pendapat dikalangan ulama fiqh. Jumhur ulama berpendapat bahwa jual beli seperti hukumnya boleh, apabila hal ini telah merupakan kebiasaan suatu masyarakat disuatu negeri, karena hal ini telah menunjukkan unsur saling rela dari kedua belah pihak. Menurut mereka, di antara unsur terpenting dalam transaksi jual beli yaitu suka sama suka (al-taradhi), sesuai dengan kandungan surat an-Nisa $(29){ }^{23}$

Dan ketiga, syarat-syarat barang yang akan ditukar dengan uang (Ma'qud 'alaih) yaitu, Barang itu ada atau tidak ada di tempat, tetapi pihak penjual menyatakan kesanggupannya untuk mengadakan barang itu. Misalnya, dalam satu toko yang besar, tidak mungkin memajang barang semuanya maka sebagian diletakkan pedagang di gudang atau masih di pabrik, tetapi secara meyakinkan barang itu boleh dihadirkan sesuai dengan persetujuan pembeli dengan penjual. Barang digudang dan dalam proses pabrik ini dihukumkan sebagai barang yang ada. Kemudian syarat selanjutnya dapat dimanfaatkan dan bermanfaat bagi manusia. Oleh karena itu, bangkai, khamr dan darah tidak sah menjadi objek jual beli, karena dalam pandangan syara' benda-benda seperti ini tidak bermanfaat bagi muslim. Kemudian syarat barangnya juga harus milik seseorang. Barang yang sifatnya belum dimiliki seseorang tidak boleh diperjualbelikan, seperti memperjualbelikan ikan di laut atau emas dalam tanah, karena ikan dan emas ini belum dimiliki penjual. Barang yang akan diperjual belikan juga boleh diserahkan saat akad berlangsung atau pada waktu yang disepakati bersama ketika transaksi berlangsung. ${ }^{24}$

\footnotetext{
${ }^{23}$ Abdul Rahman Ghazaly, et al., Fiqih Muamalat, 74.

${ }^{24}$ Abdul Rahman Ghazaly, et al., Fiqih Muamalat, 75.
} 
Selain itu menurut Teungku Muhammad Hasbi Ash-Shiddieqy dalam bukunya yang berjudul Pengantar Fiqh Muamalah Membahas Hukum Pokok dalam Interaksi Sosial-Ekonomi (edisi revisi), dalam hal yang berkaitan dengan barang atau benda yang akan diperjualbelikan harus memenuhi syarat: Dapat ditimbang, dapat diukur, dapat dihitung dan dapat disukat (dihastakan). ${ }^{25}$

\section{Macam-macam Jual Beli}

Jual beli dapat ditinjau dari beberapa segi. Ditinjau dari segi hukumnnya, jual beli ada dua macam yaitu jual beli yang dilarang oleh agama tetapi sah hukumnya, dan jual beli yang dilarang oleh agama, tetapi batal hukumnya.

Jual beli yang dilarang oleh agama, tetapi sah hukumnya yaitu jual beli yang telah memenuhi syarat dan rukunnya, tetapi ada beberapa faktor yang menghalangi kebolehan proses jual beli. Adapun macamnya antara lain sebagai berikut : Pertama, jual beli dari orang yang masih dalam tawar-menawar. ${ }^{26}$ Kedua, jual beli dengan menghadang dagangan di luar kota/pasar. ${ }^{27}$ Ketiga, jual beli najasy ${ }^{28}$ dan

${ }^{25}$ Teungku Muhammad Hasbi AshShiddieqy, Pengantar Fiqh Muamalah Membahas Hukum Pokok dalam Interaksi Sosial-Ekonomi (Edisi Revisi) (Semarang: Pustaka Rizki Putra, 2009), 33.

${ }^{26}$ Apabila ada dua orang masih tawarmenawar atas sesuatu barang, maka terlarang bagi orang lain membeli barang itu, sebelum penawar pertama diputuskan. Seperti seseorang berkata, "Tolaklah harga tawarannya itu, nanti saya yang akan membeli dengan harga yang lebih mahal". Lihat Ismail Nawawi, Fikih Muamalah Klasik dan Kontemporer (Bogor: Ghalia Indonesia, 2012), 78.

${ }^{27}$ Maksudnya adalah menguasai barang sebelum sampai ke pasar agar dapat membelinya dengan harga murah, sehingga ia kemudahan menjual di pasar dengan harga yang juga lebih murah. Tindakan ini dapat merugikan para pedagang lain, terutama yang belum mengetahui harga pasar. Jual beli seperti ini dilarang karena dapat mengganggu kegiatan pasar, meskipun akadnya sah. Lihat Ismail Nawawi, Fikih Muamalah Klasik dan Kontemporer, 78.

${ }^{28}$ Adalah seseorang menambah atau melebihkan harga temannya dengan maksud keempat, menjual di atas penjualan orang lain. ${ }^{29}$

Sedangkan jual beli yang dilarang oleh agama dan batal hukumnya, yaitu jual beli yang tidak memenuhi salah satu syarat dan rukunnya, dan akad yang tidak memenuhi salah satu syarat dan rukun tersebut termasuk akad yang batil (batal).

Adapun macamnya antara lain, pertama, jual beli barang yang zatnya haram, najis, atau tidak boleh diperjualbelikan. ${ }^{30}$ Kedua, jual beli yang barangnya tidak ada (Bai' Ma'dum). ${ }^{31}$ Ketiga, jual beli bersyarat (iwadh majlul). ${ }^{32}$

memancing-mancing orang agar orang itu mau membeli barang milik kawannya. Lihat Ismail Nawawi, Fikih Muamalah Klasik dan Kontemporer, 79.

${ }^{29}$ Menjual di atas penjualan orang lain, umpamanya seseorang berkata, "Kembalikan saja barang itu kepada penjualnya, nanti barangku yang akan kau beli dengan harga yang lebih murah dari itu. Lihat Ismail Nawawi, Fikih Muamalah Klasik dan Kontemporer, 79.

${ }^{30}$ Barang yang najis atau haram dimakan haram juga untuk diperjualbelikan, seperti babi, berhala, bangkai, dan khamar (minuman yang memabukkan). Rasulullah saw. Bersabda: أِنَّ اللّهَ وَرَسُوْلَهُ

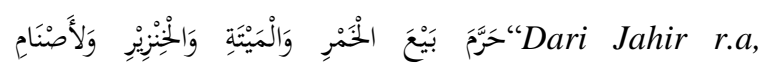
Rasulullah Saw bersabda, sesungguhnya Allah dan Rasul-Nya telah mengharamkan menjual arak, bengkai, babi, dan berhala" (Riwayat Bukhari dan Muslim). Lihat Hendi Suhendi, Fiqh Muamalah (Jakarta: Rajawali Pers, 2010), 83.

${ }^{31}$ Bai' ma'dum (jual beli yang barangnya tidak ada) yang didalamnya terdapat unsur ketidakjelasan adalah bathil. Sesuatu yang bersifat samar-samar tidak boleh untuk diperjualbelikan, karena dapat merugikan salah satu pihak, baik penjual, maupun pembeli. Yang dimaksud dengan samar-samar adalah tidak jelas, baik barangnya, harganya, kadarnya, masa pembayarannya, maupun ketidakjelasan yang lainnya. Lihat Hendi Suhendi, Fiqh Muamalah, 83.

${ }^{32}$ Jual beli yang ijab kabulnya dikaitkan dengan syarat-syarat tertentu yang tidak ada kaitannya dengan jual beli atau ada unsur-unsur yang merugikan dilarang oleh agama. Contoh jual beli bersyarat yang dilarang, misalnya ketika terjadi ijab kabul si pembeli berkata : "Baik, mobilmu akan ku beli sekian dengan syarat anak gadismu harus menjadi istriku". Atau sebaliknya si penjual berkata : "Ya, saya jual mobil ini kepadamu sekian asal anak 
Keempat, jual beli madhamin. ${ }^{33}$ Kelima, jual beli malaqih. ${ }^{34}$ Keenam, jual beli gharar. $^{35}$ Ketujuh, larangan menjual makanan hingga dua kali ditakar. ${ }^{36}$ Kedelapan, jual beli yang dilarang karena dianiaya. ${ }^{37}$ Kesembilan, jual beli muhaqalah, mukhadharah, mulamasah, munabadzah, dan muzabanah. ${ }^{38}$

gadismu menjadi istriku". Lihat Ismail Nawawi, Fikih Muamalah Klasik dan Kontemporer, 79.

${ }^{33}$ Jual beli madhamin ialah menjual sperma (mani) hewan, seperti mengawinkan seekor domba jantan dengan betina agar dapat memperoleh turunan. Lihat Ismail Nawawi, Fikih Muamalah Klasik dan Kontemporer, 79.

${ }^{34}$ Jual beli malaqih, ialah menjual janin binatang yang masih berada dalam perut induknya. Jual beli seperti ini dilarang, karena barangnya belum ada dan tidak tampak. Lihat Ismail Nawawi, Fikih Muamalah Klasik dan Kontemporer, 79.

${ }^{35}$ Jual beli gharar, yaitu jual beli yang samar sehingga ada kemungkinan terjadi penipuan. Seperti penjual ikan yang masih didalam kolam atau menjual kacang tanah yang atasnya kelihatan bagus tapi dibawahnya jelek. Lihat Ismail Nawawi, Fikih Muamalah Klasik dan Kontemporer, 79.

${ }^{36} \mathrm{Hal}$ ini menunjukkan kurangnya saling percaya antara penjual dan pembeli. Jumhur ulama berpendapat bahwa seseorang yang membeli sesuatu dengan takaran dan telah diterimanya, kemudian ia jual kembali, maka ia tidak boleh menyerahkan kepada pembeli kedua dengan takaran yang pertama sehingga ia harus menakarnya lagi untuk pembeli yang kedua itu. Rasulullah saw melarang jual beli makanan yang dua kali ditakar, dengan takaran penjual dan takaran pembeli. Lihat Hendi Suhendi, Fiqh Muamalah, 80.

${ }^{37}$ Segala bentuk jual beli yang mengakibatkan peganiayaan hukumnya haram, seperti menjual anak binatang yang masih membutuhkan (bergantung) kepada induknya. Menjual binatang seperti ini, selain memisahkan anak dari induknya juga merupakan bentuk penganiayaan terhadap anak binatang ini. Lihat Abdul Rahman Ghazaly, et al., Fiqih Muamalat, 84.

${ }^{38}$ Jual beli muhaqalah, yaitu menjual tanamtanaman yang masih di sawah atau di ladang. Hal ini dilarang agama karena jual beli ini masih samarsamar (tidak jelas) dan mengandung tipuan. Mukhadharah yaitu menjual buah-buahan yang masih hijau (belum pantas dipanen). Seperti menjual rambutan yang masih hijau, mangga yang masih kecil-kecil. Hal ini dilarang agama karena barang ini jatuh tertiup angin kencang atau layu sebelum diambil oleh pembelinya. Mulamasah yaitu jual beli
Adapun menurut jumhur ulama, fasid (rusak) dan batal (ghairu shahih) memiliki arti yang sama. Sedangkan menurut ulama Hanafiyah membagi hukum dan sifat jual beli menjadi 3 yaitu sah, batal dan fasid (rusak). (Wahbah Az-Zuhaili, AlFiqh al-Islami wa adillatuhu, 4/425). Ulama Hanafiyah membedakan antara akad yang bathil (batal), dan akad yang fasid (rusak), yaitu sebagai berikut:

1. Jual beli bathil (batal) adalah jual beli yang tidak sesuai dengan rukun dan akadnya (ketentuan asal/pokok dan sifatnya). Seperti jual beli yang dilakukan oleh orang yang tidak sesuai (karena tidak sesuai dengan syarat dan rukun), contohnya: akad yang dilakukan anak kecil yang belum mumayis dan orang gila atau jual beli sesuatu yang tidak berharga seperti bangkai, atau jual beli barang yang dilarang seperti khamar. Menurut Abu Hanifah, jual beli yang batal tidak menjadikan pertukaran kepemilikan karena rusak jual belinya.

2. Jual beli fasid adalah jual beli yang sesuai ketentuan syara' asal/pokok (syarat dan rukun), tetapi tidak sesuai dengan ketentuan syara' pada sifatnya. Seperti jual beli yang meragukan, contohnya jual beli sebuah rumah diantara banyak rumah, tetapi belum diketahui rumah mana atau rumahnya tidak jelas milik siapa. Dalam hal ini

secara sentuh-menyentuh. Misalnya, seseorang menyentuh sehelai kain dengan tangannya di waktu malam atau siang hari, maka orang yang menyentuh berarti telah membeli kain ini. Hal ini dilarang agama karena mengandung tipuan dan kemungkinan akan menimbulkan kerugian dari salah satu pihak. Munabadzah yaitu jual beli secara lempar-melempar. Seperti seseorang berkata: "Lemparkan kepadaku apa yang ada padamu, nanti ku lemparkan pula kepadamu apa yang ada padaku". Setelah terjadi lempar-melempar terjadilah jual beli. Muzabanah, yaitu menjual buah yang basah dengan buah yang kering. Seperti menjual padi kering dengan bayaran padi basah sedang ukurannya dengan ditimbang (dikilo) sehingga akan merugikan pemilik padi kering. Lihat Abdul Rahman Ghazaly, et al., Fiqih Muamalah, 85. 
hukumnya terjadi pertukaran kepemilikan dengan izin pemilik barang secara transparan, menandakan telah terjadi penyerahan dalam majlis akad yang terjadi langsung didepan penjual tanpa menutupinya.

Berikut ini adalah macam-macam jual beli yang fasid, menurut ulama' Hanafiyah diantaranya, yaitu pertama, jual beli al-majhul. ${ }^{39}$ Kedua, jual beli harta yang tidak ada/tidak terlihat barangnya $\left(B a{ }^{\prime} i\right.$ 'Ainul Gho'ibah Au Ghoiru Mari'ah). ${ }^{40}$ Ketiga, jual beli yang dilakukan oleh orang buta (Ba'i Al 'A'ma Wa Syiro'uhu). ${ }^{41}$ Keempat, jual beli barang haram (Ba'i $B i$ Tsaman Al Muharom). ${ }^{42}$ Kelima, jual beli

${ }^{39}$ Jual beli al-majhul (benda atau barang yang secara global tidak diketahui), dengan syarat kemajhulannya itu bersifat menyeluruh. Akan tetapi, apabila kemajhu'lannya (ketidakjelasannya) itu sedikit, jual belinya sah, karena hal itu tidak membawa pada perselisihan. Lihat Rachmat Syafei, Fikih Muamalah, 97.

${ }^{40}$ 'Ainul ghoibah adalah harta pilihan yang dimiliki oleh penjual, yang wujudnya nyata, namun tidak terlihat. Menjual barang yang ghoib yang tidak dapat dihadirkan pada saat jual beli berlangsung, sehingga tidak dapat dilihat oleh pembeli. Ulama Malikiyah membolehkannya, apabila sifat-sifatnya disebutkan, dengan syarat sifat-sifat itu tidak diubah sampai barang itu diserahkan. Sedangkan ulama Hanabila mengatakan bahwa jual beli seperti ini sah apabila pihak pembeli mempunyai hak khiyar (memilih), yaitu khiyar ru'yah. Lihat Rachmat Syafei, Fikih Muamalah, 97.

${ }^{41}$ Jumhur ulama membolehkanya dalam berakad jual beli, ijarah (sewa), rahn (gadai) dan hibah (pemberian). Orang buta tersebut berhak melakukan khiyar apabila mengetahui jenis, bau atau melalui daya rasanya. Atau mungkin barangnya disifati seperti sifat buah-buahan yang masih berada di pohon, karena sifat harus menjelaskan hakikat barang yang akan diperjual belikan, maka terjadilah kesamaran dalam jual beli bagi orang yang dapat melihat. Lihat Rachmat Syafei, Fikih Muamalah, 98.

${ }^{42}$ Khamr dan babi fasid karena tidak mangandung manfaat secara syar'i, jumhur menghukuminya bathil. Termasuk dalam hal ini adalah segala jenis narkoba, ganja, ophium, kokain, heroin dan sebagainya bahkan ini semua lebih parah lagi. Demikian pula jual beli rokok, mengingat keberadaannya yang membahayakan, mengganggu orang lain, juga menyia-nyiakan harta. Rasulullah tunai dan tunda (Bai' Al Ajal Wa Ba'i Inah). ${ }^{43}$ Keenam, jual beli anggur untuk di jadikan khamer (Ba'i Inab Liashiril Khamer). ${ }^{44}$ Dan ketujuh, jual beli buahbuahan atau padi-padian yang belum sempurna matangnya (Ba'i At-Tsamar Aw Az Zuru' Qobla Wujudiha Aw Sholahiha). ${ }^{45}$

Saw telah melarang menjual bangkai, khamr, babi, patung. Barangsiapa yang menjual bangkai, maksudnya daging hewan yang tidak disembelih dengan cara yang syar'i, ini berarti ia telah menjual bangkai dan memakan hasil yang haram. Lihat Rachmat Syafei, Fikih Muamalah, 98.

${ }^{43}$ Malikiyah membedakan antara jual beli ajal dan inah. Jual beli ajal adalah jual beli yang diadakan oleh pembeli dari apa yang telah dia beli kepada penjual atau wakilnya dengan pembayaran bertempo. Sedangkan jual beli inah adalah seseorang mengatakan kepada yang lain "Belilah barang daganganku ini dengan sepuluh ribu tunai, nanti aku beli lagi barang itu dari kamu dengan dua belas ribu dengan pembayaran bertempo." Lihat Rachmat Syafei, Fikih Muamalah, 98.

${ }^{44}$ Malikiyah dan Hanabilah memandang sebagaimana yang telah ditetapkan pada jual beli ajal dan inah, bahwa jual beli ini bathil. Dan yang semisalnya seperti jual beli senjata bagi Ahli Habi (orang yang berperang) atau untuk Ahli Fitnah (orang yang sedang berada dalam kondisi fitnah) atau untuk Qutha Thariq (perampok), alasannya sama, untuk mencegah kerusakan, karena sesuatu yang dapat menjerumuskan kepada keharaman adalah haram pula, walaupun dengan suatu niat. Lihat Rachmat Syafei, Fikih Muamalah, 99.

${ }^{45}$ Para ulama fiqih sepakat menyatakan bahwa jual beli buah-buahan atau padi-padian yang belum sempurna matangnya itu tidak sah. Menurut ulama Hanafiyah apabila buah-buahan itu telah ada di pohonnya tetapi belum layak panen, maka jika disyaratkan untuk memanen buah-buahan itu bagi pembeli, jual belinya adalah sah. Apabila disyaratkan bahwa buah-buahan itu dibiarkan sampai matang dan layak panen maka jual belinya fasid menurut ulama Hanafiyah, karena sesuai tuntutan akad benda yang dibeli harus berpindah tangan kepada pembeli begitu akad disetujui. Jumhur ulama menyatakan bahwa jual beli buah-buahan yang belum layak panen hukumnya batal, akan tetapi apabila buah-buahan itu telah matang tapi belum layak panen maka jual belinya sah. Sekalipun menunggu sampai benar-benar layak panen atau disyaratkan harus dipanen ketika itu juga. Lihat Rachmat Syafei, Fikih Muamalah, 99. 


\section{Jual Beli Borongan}

Dalam Kamus Besar Bahasa Indonesia (KBBI) jual beli diartikan sebagai persetujuan saling mengikat antara penjual, yakni pihak yang menyerahkan barang, dan pembeli sebagai pihak yang membayar harga barang yang dijual. ${ }^{46}$ Sedangkan borongan diartikan: borong/bo·rong/ $v$ melakukan pembelian secara besarbesaran. ${ }^{47}$ Jadi jual beli borongan adalah persetujuan atau kesepakatan yang dilakukan antara penjual dan pembeli untuk saling mengikat dalam melakukan jual beli secara besar-besaran.

Sedangkan dalam ilmu fiqh jual beli borongan dikenal dengan sebutan Al-Jizaf yang bermakna jual beli sesuatu tanpa harus ditimbang, ditakar atau dihitung. Jizaf secara bahasa artinya adalah mengambil dalam jumlah banyak. Menurut Imam Syaukani, al-jizaf merupakan sesuatu yang tidak diketahui kadarnya (kuantitasnya) secara detail.

Adapun syarat ketentuan diperbolehkannya jual beli jizaf, yaitu antara lain: (1) Objek transaksi harus bisa dilihat dengan mata kepala ketika sedang melakukan akad atau sebelumnya. (2) Penjual dan pembeli tidak mengetahui secara jelas kadar objek jual beli, baik dari segi takaran, timbangan ataupun hitungannya. (3) Jual beli dilakukan atas sesuatu yang dibeli secara partai (borongan) bukan persatuan. Akad jizaf diperbolehkan atas sesuatu yang bisa ditakar atau ditimbang, seperti biji-bijian dan sejenisnya. (4) Objek transaksi bisa ditaksir oleh orang yang memiliki keahlian dalam penaksiran. (5) Objek akad tidak boleh terlalu banyak, sehingga sangat sulit untuk ditaksir, namun juga tidak terlalu sedikit sehingga sangat mudah diketahui kuantitasnya. (6) Tanah yang digunakan sebagai tempat penimbun obyek transaksi haruslah rata, sehingga

\footnotetext{
${ }^{46} \mathrm{http}: / /$ kbbi.web.id/jualbeli. Diakses pada tanggal 12 November 2016.

${ }^{47} \mathrm{http} / / / \mathrm{kbbi}$.web.id/borong. Diakses pada tanggal 12 November 2016.
}

kadar objek transaksinya bisa ditaksir. Jika ternyata tanah dalam kondisi tidak rata, maka keduanya memiliki hak khiyar. (7) Tidak diperbolehkan mengumpulkan jual beli barang yang diketahui kadarnya. Misalnya jual beli kurma satu kilo dikumpulkan dengan apel yang berada dalam satu pohon dengan satu harga atau dua harga.

Dalam hal ini jual beli jizaf juga diartikan sama dengan jual beli borongan atau spekulatif. Yang mana adalah jual beli yang biasa ditakar, ditimbang dan dihitung secara borongan dengan tanpa ditakar, ditimbang dan dihitung akan tetapi menggunakan sistem taksiran. Para ulama sepakat atas bolehnya jual beli secara borongan berdasarkan hadist:

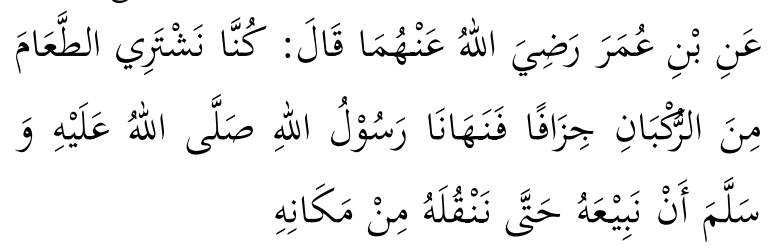

Artinya: Dari Abdullah bin Umar, dia berkata, "Dahulu kami (para sahabat) membeli makanan secara taksiran, maka Rasulullah melarang kami menjual lagi sampai kami memindahkannya dari tempat belinya”. (HR. Muslim)

Dalam jual beli borongan juga terdapat istilah lain yang serupa, tetapi maknanya berbeda yaitu "tebasan". Di kalangan petani lazim dikenal penjualan hasil panen dengan cara tebasan. Menurut Kamus Besar Bahasa Indonesia kata tebas berarti tebas $1 /$ te $\cdot$ bas $/ v$, menebas $/$ me $\cdot$ ne $\cdot$ bas $/ v$ memotong (merambah) tumbuhan yang kecil-kecil. Dari tinjauan bahasa, tebasan adalah pembelian hasil tanaman sebelum dipetik. Dalam praktiknya, tebasan dilakukan biasanya oleh tengkulak dengan cara membeli hasil pertanian atau perkebunan sebelum masa panen. 
PEMBAHASAN DAN DISKUS

\section{Bentuk-bentuk Jual Beli Bawang Merah di Desa Grinting Kabupaten Brebes}

Bentuk-bentuk jual beli bawang merah terbagi menjadi 2 bagian, yaitu: (1) Jual Beli Bawang Merah dengan Sistem Timbangan, yaitu jual beli bawang merah yang dilakukan dengan menggunakan alat ukur berupa timbangan. Dalam sistem timbangan ini bawang merah sebagai objek jual beli sudah dipanen dan sudah dipindahkan dari lahan milik petani (sawah). Dalam sistem timbangan ini terdapat 2 macam jual beli, yaitu: Rogolan dalam skala kecil dan Askip/Gedengan yang ada di toko oleh-oleh. Pertama, rogolan dalam skala kecil, maksudnya ialah bawang merah yang diperjualbelikan berada dalam jumlah yang masih bisa ditimbang dengan menggunakan timbangan. Biasanya terjadi antara tengkulak dengan pemasok/ pengirim, dan bisa juga antara pemasok dengan konsumen/ masyarakat umum untuk dikonsumsi seharihari. Seperti misalnya di pasar-pasar, atau di toko-toko penjual bawang merah dengan menggunakan timbangan, dan skalanya masih relatif kecil. Kedua, jual beli askip/ gedengan yaitu jual beli bawang merah yang sudah dipanen dan diikat daunnya menjadi satu kumpulan (satu gedeng) kemudian dikeringkan dan dibersihkan dari sisa-sisa tanah. Bawang merah yang diaskip kering biasanya dijual di toko khas oleh-oleh, dan dijual menggunakan ditimbang. Harganya pun bervariasi, karena dilihat dari bagus atau tidaknya, besar atau kecilnya kualitas dari bawang merah itu sendiri. Biasanya harganya akan jauh lebih mahal karena bawang merah yang di askip/di gedeng itu cenderung tahan lama dibandingkan yang rogolan/eceran. (2) Jual Beli Bawang Merah dengan Sistem Borongan/Taksiran (Tidak Ditimbang), yaitu jual beli bawang merah yang dilakukan dengan menggunakan sistem taksiran (perkiraan). Dalam sistem taksiran ini bawang merah sebagai objek jual beli berjumlah banyak sehingga tidak memungkinkan untuk ditimbang.
Dalam sistem ini terdapat 4 jenis jual beli taksiran, yaitu: Rogolan dalam skala besar, Askip/ Gedengan yang dijual oleh petani untuk dijadikan bibit, Borongan dengan Sistem Larikan, dan Borongan dengan Sistem Tebasan. Pertama, rogolan dalam skala besar maksudnya ialah bawang merah eceran yang diperjualbelikan berada dalam jumlah besar (bisa ber ton-ton). Biasanya masyarakat desa Grinting melakukan jual beli ini dengan sistem taksiran, dan tidak ditimbang menggunakan timbangan. Melainkan dengan melihat kualitas dan besar kecilnya bawang merah tersebut dan melihat besar karung yang digunakan. Biasanya sistem ini banyak terjadi antara tengkulak dengan pemasok/pengirim dari berbagai wilayah, yang sudah biasa melakukan transaksi dalam skala yang besar.

Kedua, askip/ gedengan yang dijual oleh petani untuk dijadikan bibit. Sebenarnya jual beli bawang merah dengan sistem askip/ gedengan di jual di toko khas oleh-oleh, tetapi petani juga biasanya menyimpan bawang merah hasil panen untuk dijadikan bibit, yang sewaktu-waktu bisa digunakan untuk bibit sendiri atau juga bisa dijual belikan apabila ada yang membutuhkan untuk ditanam lagi, hal ini bisa saja terjadi dalam keadaan memaksa, maka petani yang membutuhkan bibit tersebut harus membelinya dari petani lain. Dalam hal ini bawang merah yang dijadikan sebagai bibit disimpan dengan cara digantung (jawa: tarang). Cara ini dilakukan agar bibit yang disimpan tidak membusuk.

Ketiga, borongan dengan sistem larikan, yaitu penjualan bawang merah yang sudah dipanen dan diikat pergedeng kemudian disusun berbanjar menyerupai swatan/solokan/ bedengan seperti yang ada di lahan milik petani. Penjualan dengan sistem larikan ini dilakukan tanpa harus ditimbang terlebih dahulu melainkan cukup dengan cara menaksir kuantitasnya, berdasarkan jumlah larikan. Dengan cara banyaknya gedengan dalam satu larik dikalikan dengan perkiraan berat daripada 
bawang merah pergedengnya kemudian, dikalikan dengan banyaknya larikan. Jual beli bawang merah dengan sistem ini dilakukan antara petani dengan tengkulak, tetapi sekarang sudah jarang dipakai oleh masyarakat desa Grinting, karena jauh lebih mahal dan dilakukan apabila dalam keadaan memaksa.

Keempat, jual beli bawang merah secara tebasan, yaitu jual beli tanaman bawang merah sebelum dipetik yang dilakukan oleh petani dan tengkulak dengan mensurvei langsung ke lahan petani (sawah) untuk membeli bawang merah yang sudah cukup umur tanpa ditimbang atau dikilo terlebih dahulu. Hal ini dilakukan dengan cara menaksir atau memperkirakan besarnya kuantitas dari bawang merah yang hendak dipanen, setelah melihat dan menyaksikan bawang merah tersebut. Proses perhitungan atau taksiran yang digunakan dalam jual beli ini terdapat 3 cara, yaitu dengan metode langkahan, hitungan dan tindakan yang dilakukan oleh tengkulak.

\section{Praktik Jual Beli Bawang Merah dengan Sistem Borongan di Desa Grinting Kabupaten Brebes}

Ada dua cara dalam melakukan penjualan bawang merah, seperti yang sudah penulis sebutkan di atas, jual beli bawang merah bisa dilakukan dengan sistem timbangan dan taksiran (tidak menggunakan timbangan). Adapun dalam jual beli taksiran (tidak menggunakan timbangan) ada 4 (empat) macam, yang mana mekanismenya yaitu sebagai berikut:

Pertama, jual beli borongan dengan sisem larikan, yaitu jual beli bawang merah yang mana dalam hal perhitungannya dilakukan tanpa harus ditimbang terlebih dahulu melainkan cukup dengan cara menaksir kuantitasnya berdasarkan jumlah larikan. Dengan menggunakan cara, banyaknya gedengan dalam satu larik dikalikan dengan perkiraan berat bawang merah pergedengnya, kemudian dikalikan dengan banyaknya jumlah larikan. Jual beli bawang merah dengan sistem ini dilakukan antara petani dengan tengkulak, tetapi sekarang sudah jarang dipakai oleh masyarakat desa Grinting.

Kedua, jual beli borongan yang bersistem tebasan, merupakan cara yang paling sering dilakukan oleh petani bawang merah di Desa Grinting, karena sistem ini sudah lama sekali dipakai oleh masyarakat setempat dengan alasan sistem tebasan ini lebih efisien dan praktis dibandingkan dengan system larikan. ${ }^{48}$ Dalam praktiknya jual beli bawang merah dengan sistem tebasan dilakukan ketika 3-7 hari hendak dipanen. Pada kondisi seperti ini bawang merah sudah dapat terlihat bentuk umbinya, akan tetapi masih belum layak untuk dipanen, karena masih ada kemungkinan untuk memperbesar umbi bawang merahnya dan juga kondisi daun bawang merah masih berdiri tegak, itu menandakan bawang merah belum siap dipanen. Sebab sudah menjadi kebiasaan masyarakat setempat, jika hendak memanen bawang merah biasanya daun bawang merah sudah merebah ke tanah, sebagai tanda bawang merah siap dipanen. Mekanisme dalam melakukan jual beli bawang merah dengan cara borongan yang bersistem tebasan yaitu ada tiga cara, dengan langkah, hitungan dan tindakan. ${ }^{49}$ Cara Pertama, dengan langkahan maksudnya yaitu tengkulak harus mengitari lahan milik petani bawang merah yang hendak diborong, sambil menghitung berapa jumlah langkah yang diperoleh dari luas lahan bawang merah tersebut. Setelah dapat dipastikan berapa langkah yang didapat, selanjutnya tengkulak mengalikan perkiraan berat bawang merah perlangkah. Dari hasil perkalian tersebut merupakan hasil dari perkiraan tengkulak yang nantinya akan dipakai saat memanen bawang merah tersebut. Misalnya, petani memiliki lahan bawang merah setengah bahu, kemudian

\footnotetext{
${ }^{48}$ Wawancara dengan Ibu Saro'ah selaku petani bawang merah, Tanggal 16 April 2017 Pukul 10.00 WIB.

${ }^{49}$ Wawancara dengan Bapak Tarsono selaku tengkulak bawang merah (Juragan Bawang), Tanggal 11 Februari 2017 Pukul 11.00 WIB.
} 
tengkulak mengeceknya dengan mengitari lahan dan diperoleh 1200 langkah. Setiap satu langkah diperkirakan $2 \mathrm{~kg}$ bawang merah. Maka, 1200 langkah x $2 \mathrm{~kg}=2400$ $\mathrm{kg}$ atau 2,4 ton atau 24 kwintal hasil yang akan diperoleh saat bawang merah telah dipanen. Cara yang Kedua adalah dengan menggunakan hitungan. Metode hitungan merupakan metode untuk menaksir besarnya kuantitas/jumlah bawang merah dengan menghitung banyaknya rumpun bawang merah setiap swat/solokan (tanah yang ditinggikan dan diberi aliran air disampingnya) kemudian dikalikan dengan perkiraan berat bawang merah perkilogram. Misalnya petani memiliki tanaman bawang merah setengah bahu, terdapat 80 solokan bawang merah, setiap satu solokan terdiri dari 10 larik bawang merah, dan setiap satu larik terdapat 100 rumpun bawang merah, kemudian dikalikan dengan perkiraan setiap 100 rumpun bawang merah misal beratnya adalah $3 \mathrm{~kg}$. Maka, $3 \mathrm{~kg}$ dikalikan 10 larik dikalikan lagi 80 solokan $=2400 \mathrm{~kg}$ atau 2,4 ton atau 24 kwintal. $^{50}$ Cara yang Ketiga yaitu dengan menggunakan tindakan. metode tindakan adalah metode untuk menaksir besarnya kadar atau kuantitas bawang merah dengan memperkirakan hasil bawang merah dilihat dari luasnya lahan. Misalnya untuk luas lahan setengah bahu umumnya dapat diperoleh 600 tindakan atau setara dengan 1200 langkah, karena 1 tindakan itu terdapat 2 langkahan. Kemudian dikalikan dengan perkiraan berat bawang merah yang satu langkah itu misal $3-4 \mathrm{~kg}$ itu pun bergantung pada besar kecilnya umbi bawang merah. Cara menghitungnya hampir sama dengan cara langkahan tinggal dikalikan saja.

Ketiga, rogolan skala besar, dalam hal pengertiannya sama seperti yang telah penulis sebutkan sebelumnya, sedangkan dalam perhitungannya yang digunakan adalah dengan menggunakan system

\footnotetext{
${ }^{50}$ Wawancara dengan Bapak Wastam selaku tengkulak bawang merah (Juragan Bawang), Tanggal 26 Februari 2017 Pukul 09.30 WIB.
}

taksiran. Dilihat dari segi kualitas hasil panen yaitu bagus atau tidaknya bawang merah tersebut, besar atau kecilnya umbi bawang merah serta dilihat dari besarnya kantong (jawa: karung) yang digunakan dalam pengemasannya. Dalam hal ini tengkulak dan pemasok sudah terbiasa melakukan jual beli bawang merah dengan cara global dan tidak ditimbang, oleh sebab itu dalam teori perhitungan atau taksiran besarnya kuantitas dari bawang merah yang dikemas sudah dapat ditebak / diperkirakan dengan melihat kualitas dan besarnya kantong pengemasan.

Keempat, gedengan yang dijual oleh petani untuk dijadikan sebagai bibit, dalam hal perhitungannya (taksiran) sama dengan sistem larikan. Yaitu dengan cara memperkirakan berapa kisaran beratnya pergedeng disertai dengan melihat kualitasnya juga bagus atau tidak. Lalu barulah di lihat ada berapa gedeng yang akan dbeli dan kemudian dikalikan dengan perkiraan berat pergedengnya. Misalnya 1 gedeng bawang merah ditaksir mempunyai berat $2 \mathrm{~kg}$ kemudian dikalikan dengan jumlah gedengannya, missal ada 30 gedeng, maka $30 \times 2 \mathrm{~kg}=60 \mathrm{~kg}$ kemudian barulah di taksir harganya sesuai dengan ketetapan harga saat itu apakah sedang bagus atau tidak.

\section{Tinjauan Hukum Islam terhadap Praktik Jual Beli Bawang Merah dengan Sistem Borongan di Desa Grinting Kabupaten Brebes}

Praktik jual beli bawang merah dengan sistem borongan merupakan praktik yang diperbolehkan menurut fiqh, karena jual beli borongan termasuk dalam kategori jual beli jizaf. Pertama, pada sistem tebasan, saat akad dilakukan barang/objek akad yaitu bawang merah sudah terlihat umbinya, hal ini tidak bertentangan dengan hadits yang melarang menjual buah yang belum nampak jadinya. Penulis berpendapat bahwa jual beli borongan sudah memenuhi ketentuanketentuan syara'. Adapun dalam jual beli bawang merah meski saat melakukan akad 
borongan dengan sistem tebasan dilakukan ketika bawang merah masih belum layak untuk dipanen, tetapi bawang merah tidak membutuhkan waktu yang lama hingga layak untuk dipanen yaitu sekitar 3-5 hari. Maka kemungkinan untuk rusaknya masih kecil.

Kedua, pada sistem rogolan skala besar. Setelah peneliti memaparkan pada pembahasan sebelumnya, jual beli rogolan skala besar termasuk dalam kategori jizaf karena transaksi yang dilakukan dalam jumlah yang banyak dan tidak ditimbang melainkan dengan cara ditaksir. Selain itu proses transaksinya juga telah sesuai dengan ketentuan syara' baik dalam hal rukun maupun syaratnya karena dalam hal ini objeknya atau bawang merah sudah terlihat, mengenai taksirannya jual beli dalam skala besar ini sudah biasa terjadi diantara tengkulak dengan pemasok. Hal ini berarti jual beli rogolan skala besar telah sesuai dengan ketentuan hukum Islam.

Ketiga, sistem gedengan yang dijual oleh petani untuk dijadikan sebagai bibit, berdasarkan hasil penelitian yang penulis lakukan, jual beli gedengan yang dijual dengan tanpa menggunakan timbangan ini sesuai dengan hukum Islam. Karena jual beli ini dilakukan berdasarkan kebutuhan dan baik bagi kemaslahatan bersama, yang berarti diantara kedua belah pihak terjalin kepercayaan antar sesama serta berlandaskan pada prinsip suka sama suka (antaradin minkum). Selain itu jual beli ini juga telah memenuhi ketentuan atau syaratsyarat jizaf.

Keempat, sistem larikan, setelah peneliti melakukan penelitian terhadap jual beli dengan sistem larikan, ternyata jual beli dengan menggunakan sistem larikan ini telah sesuai dengan Hukum Islam dilihat dari segi rukun jual belinya. Yaitu objek jual beli atau bawang merah sudah terlihat (sudah dipanen) dan adanya kesepakatan diantara kedua belah pihak tentunya. Mengenai besarnya kuantitas dari bawang merah itu sendiri dapat di taksir menggunakan sistem hitungan yang sudah biasa dipakai oleh para petani dan tengkulak. Selain itu jual beli ini juga telah memenuhi ketentuan atau syarat-syarat jizaf. Oleh karena itu jual beli dengan sistem larikan di bolehkan dan telah sesuai dengan ketentuan hukum Islam.

Jual beli borongan bawang merah di Desa Grinting sudah lama diterapkan oleh masyarakat sekitar setiap tahunnya sampai sekarang ini. Masyarakat sekitar melakukan jual beli borongan setiap harinya, dan bahkan sebagian kecil dari masyarakatnya bergantung pada hasil jual beli bawang merah tersebut. Oleh karena itu kebiasaan ini bisa dikatakan dalam kategori adat dari masyarakat Desa Grinting. Adat kebiasaan ini sudah lama mendarah daging di Desa Grinting, bahkan sudah diterapkan sejak dini oleh para orang tua kepada anakanaknya, supaya kelak dapat meneruskan atau mengerti tentang jual beli bawang merah yang digeluti kedua orang tuanya. Berdasarkan kaidah fiqh, adat kebiasaan dapat dijadikan sebagai hukum. Kaidahnya sebagai berikut:

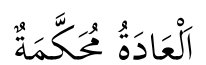

Artinya: Adat kebiasaan dapat dijadikan sebagai dasar hukum. ${ }^{51}$

Berdasarkan syarat-syarat yang telah dipaparkan menurut peneliti, dalam jual beli borongan di Desa Grinting sudah memenuhi kriteria-kriteria yang telah disebutkan. Oleh karena itu adat kebiasan dari masyarakat desa Grinting dapat diterima dan dapat dijadikan sebagai dasar hukum.

\section{KESIMPULAN}

Berdasarkan hasil penelitian di atas, dapat disimpulkan 3 (tiga) macam, yaitu pertama, bentuk-bentuk jual beli bawang merah di desa Grinting kabupaten Brebes, antara lain ada 2 macam, yaitu jual beli bawang merah dengan sistem timbangan (Rogolan skala

51 Nashr Farid Muhammad Washil dan Abdul Aziz Muhammad Azzam, Qawa'id Fiqhiyyah (Jakarta: Amzah, 2016), 5. 
kecil, Askip/Gedengan di Toko oleh-oleh) dan taksiran (Rogolan skala besar, Askip/Gedengan, Larikan dan Tebasan).

Kedua, dalam prakteknya jual beli bawang merah dengan cara borongan di desa Grinting kabupaten Brebes lebih sering dilakukan dengan menggunakan sistem tebasan, karena dianggap lebih efisien dan praktis dibandingkan dengan sistem larikan atau kiloan. Adapun mekanisme yang dipakai dalam melakukan jual beli bawang merah dengan cara borongan bersistem tebasan ada 3 cara, yaitu: (1) langkahan (2) hitungan dan (3) tindakan.

Dan ketiga, praktek jual beli bawang merah dengan sistem borongan yang dilakukan oleh masyarakat desa Grinting Kabupaten Brebes dapat dikatakan sesuai dengan prinsip-prinsip syariah, dengan berlandaskan pada jual beli borongan termasuk kedalam jual beli jizaf yang mana terdapat hadits yang membolehkannya. Sedangkan dalam persoalan hukum, kaitannya dengan bawang merah yang masih berada didalam tanah meskipun sudah terlihat umbi bawangnya, tetapi masih belum layak untuk dipanen seketika itu, maka hukumnya tetap diperbolehkan sebagaimana pendapat ulama NU dalam hasil keputusan bahtsul masa'il ke III LBM PCNU Jombang. Oleh karenanya jual beli bawang merah dengan sistem borongan ini di perbolehkan dan sah untuk dilakukan.

\section{DAFTAR PUSTAKA}

Al-Fauzan, Shaleh Bin Fuazan. Mulakhkhas Fiqih, Jilid 2. Jakarta: Pustaka Ibnu Katsir, 2013.

Ash-Shiddieqy, Teungku Muhammad Hasbi. Pengantar Fiqh Muamalah Membahas Hukum Pokok dalam Interaksi Sosial-Ekonomi (edisi revisi). Semarang: Pustaka Rizki Putra, 2009.

As-Sa'di, Abdurrahman, et.al. Fiqih Jual Beli: Panduan Praktis Bisnis Syariah, terj. Abdullah. Jakarta: Senayan Publishing, 2008.

Fatmawati, Etik. "Tinjauan Hukum Islam Terhadap Jual Beli Jeruk dengan
CaraTebasan di Desa Umbul Rejo Kecamatan Umbulsari Kabupaten Jember". Skripsi, Fakultas syar'ah IAIN Sunan Ampel Surabaya, 2012.

Ghazaly, Abdul Rahman, et al. Fiqih Muamalat. Jakarta: Kencana, 2010.

Herbiyati, Ayyun. "Tinjauan Maslahah Terhadap Jual Beli Borongan Jagung. (Studi Kasus di Desa Buntalan Kecamatan Temayang Kabupaten Bojonegooro)". Skripsi, Fakultas syari'ah IAIN Sunan Ampel Surabaya, 2011.

http://kbbi.web.id/borong. http://kbbi.web.id/jualbeli.

Lubis, Suhrawardi K. dan Farid Wajdi. Hukum Ekonomi Islam. Jakarta: Sinar Grafika, 2012.

Mardani. Fiqh Ekonomi Syariah. Jakarta: Kencana, 2012.

Moleong, Lexy J. Metode Penelitian Kualitatif. Bandung: Remaja Rosdakarya, 2014.

Na'imah, Irfatun. “Tinjauan Hukum Islam Terhadap Praktek Jual Beli Ikan dengan Sistem Tebasan di Desa Sekaran Kecamatan Sekaran Kabupaten Lamongan". Skripsi, Fakultas Syari'ah dan Hukum UIN Sunan Kalijaga Yogyakarta, 2012.

Nawawi, Ismail. Fikih Muamalah Klasik dan Kontemporer. Bogor: Ghalia Indonesia, 2012.

Departemen Agama RI. Al-Qur'an dan Terjemahnya. Jakarta: PT. Intermasa, 1986.

Sugiono. Metode Penelitian Kuantitatif Kualitatif dan $R \& D . \quad$ Bandung: Alfabeta, 2012.

Suhendi, Hendi. Fiqh Muamalah. Jakarta: Rajawali Pers, 2010.

Syafei, Rachmat. Fikih Muamalah. Bandung: Pustka Setia, 1999.

Washil, Nashr Farid Muhammad dan Abdul Aziz Muhammad Azzam. Qawa'id Fiqhiyyah. Jakarta: Amzah, 2016. 